\title{
Do the acute lymphoblastic leukemia and non-hodgkin lymphoma patients have a worse prognosis of COVID-19 infection in children?: a case report
}

\author{
DOI: https://doi.org/10.22435/hsji.v12i1.4467
}

Nadirah Rasyid Ridha, ${ }^{1,4}$ Bahrul Fikri,,${ }^{1,4}$ Rahmawaty Rahimi, ${ }^{1,4}$ Amiruddin Laompo, ${ }^{1,4}$ Conny Tanjung, ${ }^{2}$ Dasril Daud, ${ }^{1,4}$ Nasrum Massi, ${ }^{3,4}$

${ }^{1}$ Department of Pediatrics, Hasanuddin University's Faculty of Medicine, Makassar, Indonesia

${ }^{2}$ Graduate School of Medicine, Hasanuddin University, Makassar, Indonesia

${ }^{3}$ Department of Microbiology, Hasanuddin University's Faculty of Medicine, Makassar, Indonesia

${ }^{4}$ Dr. Wahidin Sudirohusodo General Hospital, Makassar, Indonesia

Corresponding author: Nadirah Rasyid Ridha

Email: nadirah.bika@gmail.com

Received: February 16, 2021; Revised: May 25, 2021; Accepted: May 31, 2021.

\begin{abstract}
Background: Coronavirus Disease 2019 (COVID-19) is a contagious disease caused by a new type of Coronavirus namely Severe Acute Respiratory Syndrome Coronavirus 2 (SARS-CoV-2). Children with tumors or autoimmune diseases are more susceptible, because of suppression of their immune system, chemotherapy, radiotherapy, or surgery on tumors.

Case presentation: We present the clinical features 3 Acute Lymphoblastic leukemia and 1 Non-Hodgkin lymphoma patients who were infected with COVID-19 since July to August 2020 in our hospital. These were the first four cases identified as COVID-19 positive in Dr Wahidin Sudirohusodo Hospital. Case 1, 2, and 4 were diagnosed as moderate and common type of COVID-19, while case 3 was classified as severe type. They may be transmitted COVID-19 infection during hospitalization. All cases were recovered from COVID-19 after a combination therapy against virus, bacteria, and also respiratory support.
\end{abstract}

Conclusion: Our case series of four pediatric cancer patients showed a good outcome after prompt treatment, suggesting that malignancy in children may not be a contributor factor for COVID-19 recovery. (Health Science Journal of Indonesia 2021;12(1):20-25)

Keywords: COVID-19, acute lymphoblastic leukemia, non-hodgkin lymphoma, children

\begin{abstract}
Abstrak
Latar belakang: Covid-19 (Coronavirus disease 2019) adalah penyakit menular yang disebabkan oleh Severe Acute Respiratory Syndrome Coronavirus 2 (SARS-CoV-2). Anak yang menderita kanker atau penyakit autoimun lebih rentan tertular karena penurunan system kekebalan tubuh, dampak kemoterapi, radioterapi, atau operasi tumor.
\end{abstract}

Penyajian kasus: Kami melaporkan 3 pasien leukemia limfoblastik akut dan 1 pasien limfoma nonHodgkin yang terinfeksi Covid-19 sejak Juli-Agustus 2020. Kasus tersebut adalah 4 kasus pertama yang teridentifikasi Covid-19 di Rumah Sakit Dr. Wahidin Sudirohusodo. Kasus 1,2, dan 4 terdiagnosis positif Covid -19 derajat sedang, sedangkan kasus 3 tergolong berat. Mereka kemungkinan terinfeksi Covid-19 saat perawatan. Semua kasus dinyatakan sembuh dari Covid-19 setelah pemberian obat anti virus, antibiotik, dan alat bantu pernapasan.

Kesimpulan: Serial kasus dari 4 pasien kanker anak dengan outcome yang baik setelah pengobatan yang cepat mengindikasikan bahwa penyakit keganasan pada anak kemungkinan bukan faktor yang berkontribusi dalam kesembuhan Covid-19. (Health Science Journal of Indonesia 2021;12(1):20-25)

Kata kunci: COVID-19, leukemia limfoblastik akut, limfoma non-hodgkin, Anak 
Coronavirus Disease 2019(COVID-19) is a contagious disease caused by a new type of Coronavirus namely Severe Acute Respiratory Syndrome Coronavirus 2 (SARS-CoV-2). ${ }^{1}$ This disease began with the emergence of unknown cases of pneumonia etiology in Wuhan, China at the end of December 2019 and has since been detected in over 100 international locations. On March 11 th 2020, the World Health Organization (WHO) characterized COVID-19 as a pandemic. ${ }^{2}$ COVID-19 spreads through rapid transmission, generally susceptible to crowds, and is characterized with a typical clinical symptoms that can be easily missed or misdiagnosed. ${ }^{3-5}$ As of July $9^{\text {th }} 2020$, WHO reported 11,874,226 confirmed cases with 545,481 deaths worldwide (Case Fatality Rate / CFR 4.6\%). Indonesia reported its first case on March 2, 2020. Cases are increasing and spreading rapidly throughout Indonesia. As of July 9, 2020, the Ministry of Health Indonesia reported 70,736 confirmed COVID-19 cases with 3,417 deaths (CFR 4.8\%). ${ }^{6}$

Children with underlying diseases are more vulnerable to COVID-19.7 Although children infected with COVID-19 are small portion of the confirmed cases, children with tumors or autoimmune diseases are more susceptible, because of suppression of their immune system, chemotherapy, radiotherapy, or surgery on tumors. ${ }^{8}$ Additionally children with leukemia may have depressed bone marrow due to chemotherapy. ${ }^{9}$ Leukemia itself or its treatments could develop an immune deficiency, malnutrition, and impairment of the mucosal membrane barriers which access for endogenous microbiological flora and other opportunistic pathogens. These will lead to severe infections of SARS-CoV-2. ${ }^{10}$ However, some papers reported the mild or asymptomatic course of COVID-19 in paediatric oncology. ${ }^{11}$ Here, we report four patients co-infected with SARS-CoV-2 within July-August 2020 at the paediatric ward Wahidin Sudirohusodo Hospital from 195 cancer patients (2\%) and describe their medical histories, clinical diagnosis, changes in clinical parameters, and outcomes.

\section{CASE PRESENTATION}

\section{Case 1}

A 2-year and 8-month-old girl was admitted to the Department of Hematology and Oncology (HO) in our hospital on 8 July 2020 because of pale, fever, and joint pain for 5 months. She received a packed red cell transfusion two times, in February and June 2020. Physical examinations revealed pallor, hepatomegaly, splenomegaly, and lymphadenopathy.
There was bleeding manifestation by petechial rash on the trunk. On admission, her laboratory results were as follows: hemoglobin, $7.1 \mathrm{~g} / \mathrm{dL}$; white blood cell count, $156.000 / \mu \mathrm{L}$ with differential count: monocytes $27.6 \%$, lymphocytes $70.1 \%$; platelet count, $25.000 / \mu \mathrm{L}$. We performed bone marrow puncture with the result of Acute lymphoblastic leukemia (ALL)-L1 and the immunophenotype corresponded to a B cell population. Based on the above data, the diagnosis of this patient was ALL-L1 high-risk group and hyperleukocytosis. She received chemotherapy with the Indonesian ALL Protocol 2018 regimen and hyperleukocytosis management on 21 July 2020. During the third day at the first week of induction phase, the patient showed symptoms of fever, cough, and dyspnea. Chest retraction and rales in both lungs were discovered. A Chest CT scan showed patch infiltrates in superior right lungs, indicating a possibility of pneumonia (Figure 1). The SARS-CoV-2 infection was confirmed by positive detection of the virus in the throat swab sample using the real-time reverse transcription-polymerase chain reaction (RT-PCR) method. The laboratory results on 20 July 2020, revealed reductions in white blood cells (WBCs) and absolute neutrophil count (ANC) in the blood. The patient was then diagnosed with COVID-19 and transferred to the isolation ward in the Department of Infectious Diseases. The symptoms were relieved after 3 days. The antibiotic of ceftazidime and amikacin were given as empirical antibacterial therapy and Oseltamivir as antiviral therapy. The patient discontinued receiving steroids due to her infection. However, the virus was sustained in the throat swab samples for several days. The patient was transferred to another isolation ward and continue chemotherapy. The SARS-CoV-2 was cleared from the patient on 10 August 2020 (Table 1).

\section{Case 2}

A 4-year and 2-month-old boy came to the emergency ward with chief complaint shortness of breath 6 days before admission and got worse 1 day before admission on August 4, 2020. Other symptoms were fever, cough, and poor appetite. He was admitted to the department of Hematology because of his past medical history of non-Hodgkin lymphoma (NHL) and routine control for chemotherapy since 19 May 2020. He has received the induction phase of chemotherapy by NHL protocol with a regimen of vincristine, cyclophosphamide, adriamycin, and methotrexate. As his clinical presentation revealed COVID-19 symptoms, we then did the chest CTscan and the result showed a ground-glass opacity 
(GGO) in both lungs, indicating the possibility of viral pneumonia (Figure 1). The SARS-CoV-2 was found in a throat swab sample by real-time PCR on 6 August 2020. Blood testing showed hemoglobin $12.2 \mathrm{gr} / \mathrm{dl}$, leukocyte $11.100 / \mu \mathrm{L}$, platelet $434.000 /$ $\mu \mathrm{L}$, reduction of lymphocyte $17.8 \%$, monocyte $11 \%$. The patient was then diagnosed as having COVID-19 and transferred to an isolation ward of our department. In the isolation ward, the patient was treated with oxygen therapy by nasal catheter, antiviral therapy with Oseltamivir, levofloxacin, and amikacin. Because the patient still had minimal chest retraction, the levofloxacin antibiotic was continued until 14 days and his clinical condition gradually improved. A re-examination of the blood test on August 17th showed hemoglobin $10.5 \mathrm{gr} / \mathrm{dl}$, leucocyte $11.100 / \mu \mathrm{L}$, platelet $434.000 / \mu \mathrm{L}$, increased lymphocyte $45.5 \%$, monocyte $10.1 \%$. The SARSCoV-2 was cleared from the patient on 11 August 2020. (Table 1)

Table 1. Summary of Clinical manifestation, laboratory examination, and clinical outcome of the four pediatric malignancy with SARS COV-2 infection

\begin{tabular}{|c|c|c|c|c|c|}
\hline Clinical Characteristic & Normal range & Case 1 & Case 2 & Case 3 & Case 4 \\
\hline Diagnosis & No & ALL-L1 HR & NHL & ALL-L1 HR & ALL-L1 HR \\
\hline $\begin{array}{l}\text { Clinical type of } \\
\text { COVID-19 }\end{array}$ & No & Moderate & Moderate & Severe & Moderate \\
\hline Nutritional status & Good nourished & Good nourished & Good nourished & Wasting & Good nourished \\
\hline NLR & $<3.13$ & 0.04 & 3.8 & & \\
\hline ALC & $>1500$ & 1064 & 1975 & 21.1 & 0.05 \\
\hline Chest CT & No & $\begin{array}{l}\text { Yes, patchy infiltrate } \\
\text { in right lobe } \\
\text { Recovery from }\end{array}$ & $\begin{array}{l}\text { Yes, ground glass } \\
\text { opacity }\end{array}$ & $\begin{array}{l}3331 \\
\text { Yes, patchy opacity } \\
\text { at both of lung }\end{array}$ & $\begin{array}{l}4370 \\
\text { Yes, multifocal } \\
\text { consolidation in the right }\end{array}$ \\
\hline Clinical outcome & & COVID-19 & $\begin{array}{l}\text { Recovery from } \\
\text { COVID-19 }\end{array}$ & $\begin{array}{l}\text { Recovery from } \\
\text { COVID-19 }\end{array}$ & $\begin{array}{l}\text { lobe. } \\
\text { Recovery from } \\
\text { COVID-19 }\end{array}$ \\
\hline
\end{tabular}

\footnotetext{
* NLR: Neutrophil Lymphocyte Ratio, ALC: absolute lymphocyte count

CT: computerized tomography
}

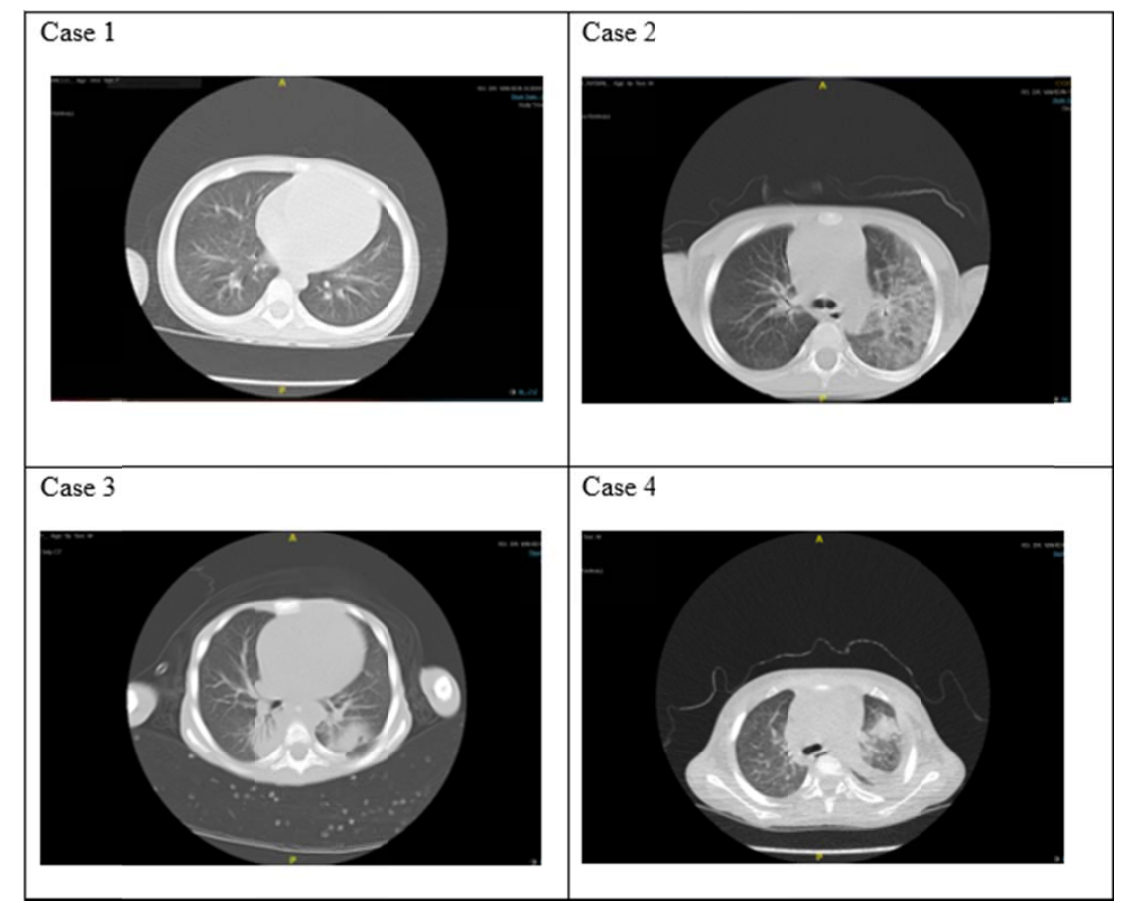

Figure 1. CT images of the four patients on diagnosed as SARS-CoV-2 infection 


\section{Case 3}

A 6-year old boy was admitted to the HO Department in our hospital on 14 July 2020 to continue chemotherapy for Acute Lymphoblastic Leukemia LI High-Risk group with infiltration of blast cells in the pancreas. He initially received his first chemotherapy using the Indonesian ALL Protocol 2018 high-risk group on 3 June 2020 based on history taking, physical examination, complete blood count, and the result of bone marrow puncture. He was in wasting with acute upper respiratory infection, hypoalbuminemia, diaper rash, acute diarrhea without dehydration. One day after admission, the patient presented with short of breathiness, found rales in both lungs, and the chest CT imaging revealed parenchymal infiltration of the lung (Figure 1) and the diagnosis of this patient was community-acquired pneumonia. We administered a combination of antibiotics with ceftazidime and amikacin. On 16 August 2020, on his $62^{\text {nd }}$ days of hospitalization, his condition worsen as reflected by desaturation. The laboratory results revealed WBC $7900 / \mu \mathrm{L}$, lymphocyte $4.2 \%$, Neutrophil Lymphocyte Ratio (NLR) 21.1, Absolute Lymphocyte Count (ALC) 331, hence, we tracked for the possibility of COVID-19 infection and planned to perform a throat swab. The SARS CoV2 infection was confirmed by positive detection of the virus in the throat swab sample using the realtime reverse transcription-polymerase chain reaction (RT-PCR) method on 17 August 2020. The patient then was diagnosed as having COVID-19 and transferred to an isolation ward at our department. In the isolation ward, the patient was treated with combination therapy including oxygen delivery via a non-rebreathing mask, antibiotics therapy with meropenem, amikacin, and Oseltamivir. The virus was persistent in the sample from the throat swab in this patient, so the patient remained in the isolation ward. The SARS-CoV-2 in the throat swab disappeared from the sample on 30 August 2020, about 13 days after the first time of positive detection of the virus. (Table 1)

\section{Case 4}

A 4-year and 2-month-old boy was transferred from district hospital on 10 August 2020 with the main complaint of paleness in the last 2 weeks before admission. There was fever and shortness of breath for 2 days before admission also gum bleeding 4 days before admission. On physical examination the child was conscious, increased body temperature, lymphadenopathy, the liver was palpable at $8 \mathrm{~cm}$ below costal arch margin and left lobe $7 \mathrm{~cm}$ below xiphoid process with supple, smooth surface, sharp edge with no tenderness. The spleen was palpable on Schuffner I. From the genital examination, there were palpable left testes with a size of $2 \times 1 \times 1 \mathrm{~cm}$, and right palpable testes with a size of $4 \times 3 \times 2 \mathrm{~cm}$. The laboratory results revealed leucocyte $169.000 / \mu \mathrm{L}$, hemoglobin $3.8 \mathrm{gr} / \mathrm{dl}$ and platelet $2000 / \mu \mathrm{L}$, differentiation: neutrophil $0 \%$, monocytes $54.4 \%$, lymphocytes $60 \%$; NLR 0, ALC 27.937. Bone marrow puncture showed ALL-L1. We diagnosed this patient with ALL-L1 high-risk group and hyperleukocytosis. $\mathrm{He}$ has received chemotherapy with intrathecal methotrexate and oral dexamethasone, aggressive hydration and allopurinol. On the 5th day of hospitalization, the patient presented a cough and shortness of breath. The patient was suspected to be infected with COVID-19, and the chest CT imaging revealed multifocal consolidation in the right lobe (Figure 1). The SARS-CoV-2 was found in a throat swab sample by real-time PCR. The patient was then diagnosed as having COVID-19 and transferred to an isolation ward of our department. The patient received meropenem and amikacin as antimicrobial therapy and Oseltamivir as antiviral therapy. However, intravenous and oral chemotherapy was discontinued. Chemotherapy is an immunosuppressant that suppresses the immune system; however, in patients with COVID-19, immunity is significantly reduced, so iv and oral chemotherapy may worsen the illness. As a result, it was decided to temporarily stop the therapy until the patient recovered from COVID-19. The delay in chemotherapy will undoubtedly have an impact on the patients' outcomes, and it has created a new problem in the management of cancer patients. The SARS-CoV-2 in the throat swab was cleared from the sample on 27 August 2020 (Table 1).

\section{DISCUSSION}

Our study reported 4 cases of pediatric cancer with SARS-CoV-2 infection in Makassar, South Sulawesi Indonesia. All children infected with COVID-19 were successfully recovered from the infection with mild to severe symptoms. They showed symptoms of SARS-CoV-2 like fever and shortness of breathiness during hospitalization. Zimmermann et $a l^{12}$ described that most common symptom COVID-19 in children is fever $(50 \%)$ and cough $(38 \%) .{ }^{13}$ In our study, we found 3 out of 4 cases had history of fever. They developed fever and other symptoms related to 
COVID-19 after chemotherapy, which might indicate that the SARS-CoV-2 nosocomial infection. ${ }^{7,14}$

Early studies showed reduction in lymphocytes during SARS-CoV-2 infection, and we observed the various range of blood laboratory results in our study. Case 3 had a decreased count of lymphocytes in the blood, which may be attributed to the severity of COVID-19. The cause of wasting in cancer patients is caused by a variety of factors. it is divided into two categories; nutritional deficiencies and malabsorption, and metabolic disorders. Wasting has an effect on therapy response, complications, quality of life, and patient survival. particularly in these cases, because in addition to cancer, they were also found to be COVID-19 positive. Therefore, we have to pay a close attention to nutrition management. Yang $\mathrm{K}$, et $a l^{3}$ described the results of meta-analysis that lower lymphocyte count was associated with increased mortality, ARDS, and severe COVID-19. The association seemed to be stronger in younger patients compared to older patients. In case 3, the condition of the patient classified severe COVID-19 and the need for ICU care. Case 1 and 4 had an increased count of lymphocytes in the blood, which may be attributed to their underlying disease, ALL. In ALL patients, we usually found an increase in lymphocyte count because of increased proliferation lymphoblast in bone marrow caused by malignancy. NLR and ALC in this case could not be utilized as a parameter to assess the severity of the disease, mainly because leukocyte in leukemia patients usually increased and can sometimes be hyperleukocytosis. ${ }^{15}$ The diagnosis of COVID-19 was based on symptoms, lung X-ray/CT examination, and detection of the virus by real-time RT-PCR in throat swab samples from the patients. ${ }^{16}$ The main basis for the diagnosis of infections with SARS-CoV-2 is real-time polymerase chain reaction (RT-PCR) on upper or lower respiratory secretions. ${ }^{17}$

Children with underlying diseases and suspected to be infected by COVID-19 should be observed with extended isolation time and tested with more nucleic acid detections. They should also receive early symptomatic treatment. Supportive treatment including sufficient fluid and calorie intake and additional oxygen supplementation should be used in the treatment of children infected with SARS$\mathrm{CoV}$ 2. The aim is to prevent ARDS, organ failure, and secondary nosocomial infections. If a bacterial infection is suspected, broad-spectrum antibiotics such as second or third-generation cephalosporins may be used. ${ }^{12}$ The most commonly used antibiotics in children were meropenem and linezolid. ${ }^{18}$ And in our study, all of the cases received antiviruses like Oseltamivir and antimicrobial therapy such as ceftazidime, meropenem, and amikacin. During the observation, there were no side effects of the given medication, and the patients' tolerance was good.

Disease clusters and nosocomial infections have been reported. The proportion of nosocomial infections is high among diagnosed infections, and medical staff are at high risk of infection. One study on 44,672 patients showed that health workers accounted for $3.8 \%$ of the COVID-19 cases and five health workers died as a result of the infection. ${ }^{19}$ Since the specific medicine for COVID-19 is still not available, the prevention of nosocomial infections will be the key. The high presence of the COVID-19 epidemic in the media is likely to improve the general public's awareness. People with symptoms indicating a SARS-CoV-2 infection should take protective measures during the hospital or clinic visit, such as wearing a mask, minimizing the time of stay in the hospital, and if possible, making remote medical consultations in advance. ${ }^{20}$ Medical institutions should formulate infection prevention and control strategies, and strengthen the hospital's infection prevention and control efforts, such as the establishment of special departments for outpatients with fever, and a notification triage system. Triage of early identification among suspected cases can avoid excessive gathering of patients in the hospital. Isolation wards should be established for suspected and confirmed patients needing treatment. In hospitals without single isolation wards or negative pressure isolation, indoor ventilation measures should be taken timely, and the management of patients should be standardized in these wards. Using adequate disinfection procedures can reduce the possibility of hospital transmission of the virus. During the epidemic, the possibility of the outbreak of nosocomial infection, and establish an early warning mechanism. Emergency plans or measures should be developed to deal with nosocomial infections., ${ }^{3,21}$

The report's limitation was a small sample size, so it could not be statistically analyzed. It is suggested that a larger sample size and a better study design be used. The number of COVID-19 in children is much smaller than adult. Our case series of ALL and NHL pediatric patients showed a good outcome after prompt treatment, suggesting that malignancy in children may not be a contributor factor for COVID-19 mortality. COVID-19 is a deadly disease that can lead to death. Nevertheless, in this case report, 
despite the fact that COVID-19 was confirmed in the cancer patients, they recovered after medication and observation. However, more research with more cases was required to support that claim.

\section{REFERENCES}

1. Li Q, Guan X, Wu P, et al. Early transmission dynamics in Wuhan, China, of novel coronavirusinfected pneumonia. N Engl J Med. 2020;382:1199207.

2. World Health Organization. Global Situation Report-55 15 March 2020. 2020.

3. Yang $\mathrm{K}$, Sheng $\mathrm{Y}$, Huang $\mathrm{C}$, et al. Clinical characteristics, outcomes, and risk factors for mortality in patients with cancer and COVID-19 in Hubei, China: a multicentre, retrospective, cohort study. Lancet Oncol. 2020;21: 904-13.

4. Rothe C, Schunk M, Sothmann P, et al. Transmission of 2019-NCOV infection from an asymptomatic contact in Germany. N Engl J Med. 2020;382:970-1.

5. Holshue ML, DeBolt C, Lindquist S, et al. First case of 2019 novel coronavirus in the United States. N Engl J Med. 2020;382:929-36.

6. Menteri Kesehatan Republik Indonesia. Keputusan Menteri Kesehatan Republik Indonesia Nomor HK.01.07/MenKes/413/2020 Tentang Pedoman Pencegahan dan Pengendalian Corona Virus Disease 2019 (COVID-19). 2020.Indonesian.

7. Wang $\mathrm{D}, \mathrm{Hu} \mathrm{B}, \mathrm{Hu} \mathrm{C}$, et al. Clinical characteristics of 138 hospitalized patients with 2019 novel coronavirus-infected pneumonia in Wuhan, China. JAMA. 2020;323:1061-9.

8. Al-Quteimat OM, Amer AM. The impact of the COVID-19 pandemic on cancer patients. Am J Clin Oncol. 2020;1-4.

9. Erdem AY, Ozbek NY. SARS COV-2 infection in children with Leukemia. Turkish J Pediatr Dis. 2020;14(Suppl):41-7.

10. Cakir B. COVID-19 and children: from an epidemiological perspective. Turkish J Pediatr Dis. 2020;14(Suppl): 1-8.

11. Hrusak O, Kalina T, Wolf J, et al. Flash survey on severe acute respiratory syndrome coronavirus-2 infections in paediatric patients on anticancer treatment. Eur J Cancer. 2020; 132:11-6.

12. Zimmermann P, Curtis N. Coronavirus infections in children including COVID-19: an overview of the epidemiology, clinical features, diagnosis, treatment and prevention options in children. Pediatr Infect Dis J. 2020;39:355-68.

13. Ogimi C, Englund JA, Bradford MC, et al. Characteristics and outcomes of coronavirus infection in children: the role of viral factors and an immunocompromised state. J Pediatric Infect Dis Soc. 2019;8:21-8.

14. Zhou Q, Gao Y, Wang X, et al. Nosocomial infections among patients with COVID-19, SARS and MERS: a rapid review and meta-analysis. Ann Transl Med. 2020;8:629.

15. Bernard SC, Abdelsamad EH, Johnson PA, et al. Pediatric leukemia : diagnosis to treatment - a review. J Cancer Clin Trials. 2017;2:1-3.

16. Yamamoto L, dos Santos EH, Pinto LS, et al. SARSCoV-2 infections with emphasis on pediatric patients: a narrative review. Rev Inst Med Trop Sao Paulo. 2020;62:e65.

17. She J, Liu L, Liu W. COVID-19 epidemic: disease characteristics in children. J Med Virol. 2020;92:74754.

18. Chen ZM, Fu JF, Shu Q, et al. Diagnosis and treatment recommendations for pediatric respiratory infection caused by the 2019 novel coronavirus. World J Pediatr. 2020;16:240-6.

19. Chan JFW, Yuan S, Kok KH, et al. A familial cluster of pneumonia associated with the 2019 novel coronavirus indicating person-to-person transmission: a study of a family cluster. The Lancet. 2020;395:514-23.

20. Alshamrani M, AlHarbi A, Alkhudair N, et al. Practical strategies to manage cancer patients during the COVID-19 pandemic: Saudi oncology pharmacy assembly experts recommendations. J Oncol Pharm Pract. 2020;26:1429-40.

21. Saxena S, Kumar CM. Anaesthetic management of patients with COVID-19: infection prevention and control measures in the operating theatre. Comment on Br J Anaesth 2020; 125:e239-e241. Br J Anaesth. 2020;125,e317-e318. 